\title{
Pelatihan Pelaporan Keuangan Berbasis Aplikasi di Lingkup Antar RT dalam RW Kelurahan Kauman Kecamatan Klojen Malang
}

\author{
Sutrisno $^{1 *}$, Imam Cholissodin ${ }^{2}$, Arief Andy Soebroto ${ }^{3}$, Dian Eka Ratnawati ${ }^{4}$, \\ Lailil Muflikhah ${ }^{5}$ \\ 1,2,3,4,5 Program Studi Teknik Informatika, Fakultas Ilmu Komputer, Universitas Brawijaya, \\ JL. Veteran No.8, Malang, 65145, Indonesia \\ e-mail corresponding author : trisno@ub.ac.id. HP. 081249542011
}

\begin{abstract}
ABSTRAK
Pemanfaatan teknologi informasi dan komunikasi untuk aplikasi keuangan berbasis online telah banyak dikembangkan, diantaranya di bidang perbankan, keuangan, transportasi, jual beli, kesehatan, dan sebagainya. Demikian juga aplikasi berbasis perangkat bergerak seperti telepon seluler, komputer, laptop maupun lainnya juga sudah lazim dan banyak digunakan oleh masyarakat. Berdasarkan kondisi tersebut, maka dilaksanakan kegiatan pengabdian masyarakat antar RT dalam satu RW di wilayah Kelurahan Kauman Kecamatan Klojen Kota Malang (khususnya RT-02 dan RT-03 di RW-03) untuk menggunakan aplikasi keuangan. Aplikasi yang dikembangkan diharapkan dapat mempermudah dalam melakukan pengelolaan keuangan di tingkat RT, sehingga lebih efektif, efisien, akurat dan transparan. Tahapan kegiatan pengabdian kepada masyarakat ini diawali dengan melakukan observasi dan survei khususnya RT-02 dan RT-03 di RW-03 Kelurahan Kauman Kecamatan Klojen Kota Malang. Hasil survei ini dijadikan dasar implementasi aplikasi keuangan yang dikembangkan. Selanjutnya dilakukan sosialisasi dan pelatihan penggunaan aplikasi yang telah berhasil dikembangkan dari referensi terpilih, agar masyarakat lebih terbiasa dalam menggunakan sistem layanan keuangan tersebut. Dengan adanya aplikasi ini, diharapkan pengelolaan layanan keuangan menjadi lebih mudah dan pengguna aplikasi juga dimudahkan dengan adanya fitur-fitur yang telah disediakan. Hasil dari kegiatan ini yaitu, Sistem Pengelola Keuangan RT (SIPUT) dapat diakses dalam berbagai platform baik perangkat PC desktop maupun web, lalu sistem ini menggunakan tampilan yang user friendly sehingga Staff RT02 dan RT-03 RW-03 Kelurahan Kauman dapat dengan mudah melakukan manajemen pengelolaan keuangan dengan cepat dan akurat, sehingga kinerja mereka menjadi lebih baik. Jadi SIPUT ini sangat sesuai dengan kebutuhan objek pengabdian masyarakat. Staff RT dapat melakukan berbagai pengelolan beberapa kegiatan seperti membuat manajemen keuangan, manajemen surat, dan manajemen kegiatan warga.
\end{abstract}

Kata kunci : sistem; pengelola keuangan; Kauman; teknologi web; dekstop

\section{ABSTRACT}

The use of information and communication technology for online-based financial applications has been widely developed, including in the fields of banking, finance, transportation, buying and selling, health, and so on. Likewise, mobile device-based applications such as cell phones, computers, laptops and others are also common and are widely used by the public. In accordance

Cara Mengutip : Sutrisno, S., Cholissodin, I., Soebroto, A.A., Ratnawati, D.E., Muflikhah, L. (2020).

Pelatihan Pelaporan Keuangan Berbasis Aplikasi di Lingkup Antar RT dalam RW Kelurahan Kauman Kecamatan Klojen Malang. JAST: Jurnal Aplikasi Sains dan Teknologi, 4 (1), 68-74.

doi:http://dx.doi.org/10.33366/jast.v4i1.1593

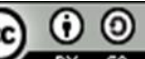

Co SA Content from this work may be used under the terms of the Creative Commons AttributionShareAlike 4.0 International License. Any further distribution of this work must maintain attribution to the author(s) and the title of the work, journal citation and DOI. 
with these conditions, a community service activity was carried out in several RTs in one RW in Kauman Sub-District, Klojen District, Malang City (specifically RT-02 and RT-03 in RW-03) to use a financial application. The developed application is expected to facilitate financial management at the RT level, so that it becomes more effective, efficient, accurate and transparent. The stages of community service activities began with observations and surveys, especially in RT-02 and RT-03 in RW-03 Kauman Sub-District, Klojen District, Malang. The results of this survey formed the basis for implementing the financial application that was developed. After that, socialization and training on the use of applications that had been successfully developed from selected references were performed, so that the people were more accustomed to using the financial service system. With this application, it is hoped that the management of financial services will become easier and application users will also be facilitated by the features provided. The results of this activity are that RT Financial Management System (SIPUT) can be accessed in various platforms both desktop $P C$ and web devices, and this system uses a user friendly display so that RT-02 and RT-03 Staffs in $R W-03$ Kauman Sub-District can easily conduct financial management quickly and accurately that improves their performance. Therefore, SIPUT is very suitable with the needs of the object of community service. RT staffs can carry out a variety of management of several activities such as making financial management, mail management, and citizen activity management.

Keywords : system; financial management; kauman; web technology; desktop

\section{PENDAHULUAN}

Sistem pengelolaan layanan keuangan merupakan hal yang sangat penting dalam kehidupan masyarakat dalam upanya meningkatkan transparansi dan kepercayaan masyarakat

Beberapa layanan pengelolaan keuangan mulai dari tingkat RT sampai kelurahan sudah mulai berbenah dalam upaya meningkatkan layanan kepada masyarakat. Pemerintah saat ini sedang giat dalam melakukan perbaikan dan peningkatan layanan masyarakat. Salah satu fasilitas layanan yang perlu dibenahi dan diperbaiki adalah layanan keuangan untuk iuran warga di tingkat RT.

Berdasarkan dari kunjungan pada lokasi dari Gambar 1, pertumbuhan jumlah warga semakin meningkat, khususnya di lingkungan RT dalam RW di Kelurahan Kauman, kecamatan Klojen, Kota Malang. Untuk itu, sudah seharusnya perlu diimbangi dengan peningkatan fasilitas layanan masyarakat. Ditingkat RT sudah sangat membutuhkan aplikasi pelayanan keuangan yang memadai. Namun, penerapan penggunaan aplikasi keuangan di lingkungan RT bukan hal yang mudah dilakukan, karena masyarakat sudah terbiasa dengan pencatatan secara manual di kartu iuran dan kemudian distempel. Untuk itu, diperlukan pengembangan sistem yang memadai disertai dengan memberikan pelatihan dalam mengoptimalkan penggunaan aplikasi layanan keuangan yang telah dikembangkan [2].

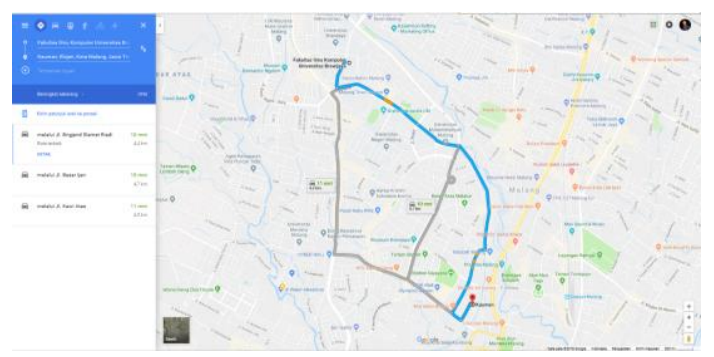

Gambar 1. Peta Lokasi Antar RT dalam RW Kel. Kauman Malang

Semakin tinggi jumlah warga masyarakat menyebabkan pencatatan secara manual menjadi tidak memadai. Dimana, saat ini proses operasional pelayanan iuran keuangan di lingkungan 
RT-02 dan RT-03 RW-03 kelurahan Kauman kecamatan Klojen Kota Malang dilakukan melalui proses penyelesaian administrasi, dilanjutkan pemeriksaan ketua RT, dan berakhir pada pemberian stempel yang cukup membutuhkan alur dan waktu yang panjang. Sehingga seringkali warga masyarakat mengeluhkan cara pelayanan tersebut.

Teknologi ICT telah berkembang sangat pesat, sehingga banyak yang dapat di-lakukan untuk mengoptimalkan suatu proses yang sebelumnya dilakukan secara manual, diubah menjadi berbasis aplikasi perangkat lunak. Hal ini sangat memungkinkan diterap-kan juga untuk fasilitas layanan keuangan masyarakat dilingkungan RT-02 dan RT-03 RW-03 kelurahan Kauman kecamatan Klojen Kota Malang, sehingga seluruh proses yang panjang dapat dipersingkat dan dimaksimalkan.

Efisiensi beberapa proses layanan keuangan seperti ketelitian pencatatan, kemudahan dalam membuat laporan sampai dalam melakukan perbaikan data jika terjadi kesalahan sangat penting ditingkatkan, khususnya di lingkungan RT-02 dan RT-03 RW-03 kelurahan Kauman kecamatan Klojen Kota Malang. Apabila dicermati, penggunaan fasilitas layanan keuangan dapat dipermudah dengan beberapa cara, diantaranya dengan pemanfaatan teknologi berbasis aplikasi. Pemanfaatan teknologi ini bisa sangat luas penerapannya, misal pada platform Android (mobile) yang paling banyak digunakan oleh masyarakat untuk berkomunikasi atau keperlua lainnya, maupun perangkat komputer pribadi dan laptop.
Berdasarkan latar belakang pemikiran tersebut, maka akan dilaksanakan kegiatan pengabdian masyarakat di lingkungan RT02 dan RT-03 RW-03 kelurahan Kauman kecamatan Klojen Kota Malang untuk melakukan perbaikan model layanan keuangan berbasis aplikasi. Dengan aplikasi ini memungkinkan ketua RT maupun warga masyarakat yang telah terdaftar dapat selalu memantau dari lokasi manapun. Aplikasi ini juga bisa mampu memberikan informasi jumlah tagihan yang sedang berjalan serta estimasi waktu warga harus melakukan pembarayan pada waktu berikutnya. Dengan cara ini, diharapkan tidak akan terjadi warga kehilangan kartu pembayarannya, atau takut salah saat pencatatan jumlah pembayaran ataupun kurang bayarnya, karena dapat dengan mudah dipantau oleh ketua RT maupun warga. Selain itu dengan adanya sistem ini, waktu pen-gecekan dana yang masuk dan keluar setiap hari atau pada interval waktu tertentu akan dapat dilakukan dengan mudah dan dapat mengetahui lebih detail dari setiap bagian laporan keuangan.

\section{METODE KEGIATAN}

Tahapan-tahapan pendukung untuk metodologi kegiatan ini, yang dilaksanakan pada hari Ahad, 7 Oktober 2018 meliputi informasi terkait referensi aplikasi Sistem Pengelola Keuangan RT (SIPUT), peraturan tentang tatakelola administrasi keuangan ditingkat RT dan RW khususnya di wilayah kota Malang, serta teori pengembangan aplikasi pada perangkat lunak [3][4]. Kemudian diikuti dengan beberapa langkah berikut. 
- Analisis dan Identifikasi Kebutuhan

Tahapan ini sebagai tahapan awal untuk melakukan identifikasi kebutuhan sistem keuangan berbasis aplikasi perangkat lunak, sehingga dapat diidentifikasi dengan baik siapa saja yang membutuhkan pelayanan keuangan dan apa saja yang dibutuhkan terkait pelayanan keuangan warga masyarakat di lingkungan RT-02 dan RT-03 RW-03 Kelurahan Kauman RT02 dan RT-03 RW-03 Kelurahan Kauman kecamatan Klojen Kota Malang.

\section{- Desain Model Sistem}

Desain model sistem merupakan panduan yang digunakan untuk melakukan implementasi dari kebutuhan sistem secara keseluruhan. Desain model sistem menggambarkan proses mulai dari data masukan, proses pengolahan data, hingga proses akhir yaitu mengeluarkan hasil dari sistem. Desain model memberikan gambaran hubungan antara satu bagian atau komponen sistem dengan bagian yang lainnya. Secara umum blok model sistem keseluruhan dibagi menjadi tiga bagian yaitu blok sistem pemasukan data keuangan, blok sistem untuk pengeluaran keuangan, dan blok sistem untuk pembuatan laporan.

- Instalasi Aplikasi Sistem Keuangan

Penerapan Sistem Pengelolaan Keuangan berbasis perangkat lunak ini dilakukan sesuai dengan desain model sistem yang telah dibuat. Desain model sistem yang telah dibuat diharapkan menjadi acuan dan panduan utama dalam menerapkan atau menginplementasikan sehingga apa yang telah direncanakan dapat diimplementasikan menjadi sebuah sistem utuh yang dapat mendukung proses bisnis pada sistem keuangan yang dibuat.

- Pelatihan Penggunaan Aplikasi Sistem Keuangan

Kegiatan pelatihan dan pendampingan dilakukan kepada administrator yang ditunjuk oleh sekretaris atau ketua RT-02 dan RT-03 RW-03 Kelurahan Kauman RT-02 dan RT-03 RW-03 Kelurahan Kauman kecamatan Klojen Kota Malang yang akan melakukan pengelolaan data keuangan. Selain kegiatan pelatihan dan pendampingan, diperlukan juga tahap pembuatan tutorial atau cara menggunakan aplikasi. Publikasi dan juga informasi disampaikan berupa banner atau pamflet yang diletakan pada pos RT-02 dan RT-03 RW-03 Kelurahan Kauman RT-02 dan RT-03 RW-03 Kelurahan Kauman kecamatan Klojen Kota Malang, sehingga warga dianjurkan untuk bisa menggunakan aplikasi untuk mempermudah pelayanan, diantaranya terkait dengan proses pembayaran iuran atau pelayanan lainnya. Pelatihan dan publikasi cara-cara penggunaan aplikasi dilakukan untuk memberikan gambaran yang jelas bagaimana aplikasi dapat membantu terhadap pelayanan warga. Administrator atau pengelola data penjadwalan layanan diharapkan dapat terbiasa mengoperasikan aplikasi dengan mudah.

Mekanisme pelatihan yang dilakukan adalah dengan pembelajaran metode direct instruction, demonstrasi dan eksperimen yang mana trainer memberi penjelasan uraian materi 
terkait dengan sistem pengelola keuangan, kemudian didemonstrasikan dan dilanjutkan dengan peserta mencobanya langsung. .Pelatihan ini dilakukan dalam sekali. Dalam pelatihan tersebut diberikan juga video cara penggunaan sehingga dapat digunakan sebagai pelatihan di lain hari. Selain itu, peserta diberikan sebuah modul yang memuat materi yang berkaitan dengan sistem aplikasi ini.

- Penulisan Laporan

Aplikasi sistem keuangan berbasis aplikasi ini akan dievaluasi secara bertahap, dengan membuat catatancatatan yang dianggap penting dan perlu. Catatan ini akan didokumentasi dengan baik untuk menginventarisasi semua kejadian atau permasalahan yang ditemukan sejak sistem ini diterapkan di RT-02 dan RT-03 RW-03 Kelurahan Kauman RT-02 dan RT-03 RW-03 Kelurahan Kauman kecamatan Klojen Kota Malang. Hal ini sangat diperlukan agar dapat digunakan untuk bahan laporan pertanggungjawaban kegiatan Pengabdian Masyarakat sekaligus sebagai bahan evaluasi untuk dapat secara berkelanjutan bisa dikembangkan dan digunakan untuk lingkungan RT-RW ditempat lain.

\section{KARYA UTAMA}

Pada Tabel 1, beberapa hasil yang telah diperoleh pada kegiatan pengabdian akan dievaluasi melalui identifikasi faktor kendala serta bagaimana solusi terbaiknya. Kemudian digunakan pula parameter efektifitas dan efisiensi pengukuran hasil kegiatan pengabdian berupa kuisioner dengan beberapa pertanyaan terhadap sistem yang digunakan dan penilaian responden ketika kegiatan pengabdian masysrakat tersebut selesai dilaksanakan. Sehingga capaian kegiatan dapar diukur dengan optimal.

Tabel 1. Hasil Kegiatan Pengabdian

\begin{tabular}{|c|c|c|}
\hline No & Kegiatan & Hasil \\
\hline 1 & $\begin{array}{l}\text { Identifikasi kondisi RT- } \\
02 \text { dan RT-03 }\end{array}$ & $\sqrt{ }$ \\
\hline 2 & $\begin{array}{l}\text { Menyambung relasi dan } \\
\text { pengabdian masyarakat } \\
\text { secara professional }\end{array}$ & $\sqrt{ }$ \\
\hline 3 & $\begin{array}{l}\text { Memperjelas kebutuhan } \\
\text { RT-02 dan RT-03 RW- } \\
\text { 03 Kelurahan Kauman } \\
\text { mengenai sistem } \\
\text { informasi yang akan } \\
\text { dibangun }\end{array}$ & $\sqrt{ }$ \\
\hline 4 & $\begin{array}{l}\text { Merancang desain dan } \\
\text { implementasi dengan } \\
\text { memilihkan SIPUT } \\
\text { sebagai aplikasi referensi }\end{array}$ & $\sqrt{ }$ \\
\hline 5 & $\begin{array}{l}\text { Implementasi SIPUT } \\
\text { sudah didemokan ke RT- } \\
\text { 02 dan RT-03 RW-03 } \\
\text { Kelurahan Kauman }\end{array}$ & $\sqrt{ }$ \\
\hline 6 & $\begin{array}{l}\text { Staff RT-02 dan RT-03 } \\
\text { RW-03 Kelurahan } \\
\text { Kauman mampu } \\
\text { mengoperasikan program } \\
\text { SIPUT dengan mudah }\end{array}$ & $\sqrt{ }$ \\
\hline 7 & $\begin{array}{l}\text { Mengetahui efisiensi dan } \\
\text { efektifitas dari penerapan } \\
\text { aplikasi SIPUT }\end{array}$ & $\sqrt{ }$ \\
\hline 8 & $\begin{array}{l}\text { Mampu memberikan } \\
\text { aplikasi SIPUT sesuai } \\
\text { dengan kebutuhan RT- } \\
\text { RT dalam lingkup RW di } \\
\text { Kauman }\end{array}$ & $\sqrt{ }$ \\
\hline 9 & $\begin{array}{l}\text { Memberikan bentuk } \\
\text { laporan } \\
\text { pertanggungjawaban } \\
\text { terhadap seluruh } \\
\text { kegiatan pengabdian di } \\
\text { RT-02 dan RT-03 RW- } \\
\text { 03 Kelurahan Kauman }\end{array}$ & $\sqrt{ }$ \\
\hline
\end{tabular}


Pada kegiatan ke-1, melakukan survey secara langsung ke RT-02 dan RT03 RW-03 Kelurahan Kauman. Kendala yang dihadapi adalah waktu kunjungan dari tim. Solusi yang dilakukan adalah kunjungan dilakukan pada jam tertentu. Kemudian pada kegiatan ke-2 tidak ditemukan kendala. Dalam kegiatan ke-3 kendala yang dihadapi adalah data penduduk kelurahan terbaru yang sulit didapatkan, solusi yang diambil adalah mengambil data penduduk pada tahun sebelumnya. Kemudian pada kegiatan ke4 merancang desain dan implementasi SIPUT. Hanya terdapat beberapa kendala kecil seperti tidak berjalannya fitur seperti yang diharapkan. Namun kendala tersebut dapat diatasi dengan baik. Pada kegiatan ke-5 tidak ditemukan kendala dalam lapangan. Kemudian pada kegiatan ke-6 kendala yang dihadapi adalah waktu yang terbatas dikarenakan kesibukan staff RT02 dan RT-03 RW-03 Kelurahan Kauman. Solusi yang dilakukan adalah memilih waktu yang tepat sehingga pelaksanaan training dapat berjalan dengan baik. Pada kegiatan ke-7 yaitu evaluasi hasil kerja SIPUT kendala yang terjadi adalah staff kurang terbiasa dengan aplikasi. Solusi yang dilakukan adalah melakukan monitoring secara periodik pada aplikasi. Pada kegiatan ke-8 dan ke-9 tidak ditemukan kendala dalam lapangan. Berikut beberapa bukti kegiatan pengabdian tersebut, seperti ditunjukkan pada Gambar 2 dan hasil evaluasi sistem dan ketika pelaksanaan kegiatan pada Gambar 3 dan 4. Gambaran Ipteks yang akan ditransfer pada mitra, yaitu pengurus RT dan warga dapat dengan mudah melakukan entri data keuangan lebih cepat, lalu pengurus RT dapat terbantu dalam hal pendataan keuangan masuk dan keluar menggunakan sistem yang sudah terkomputerisasi. Sehingga mampu meningkatkan pelayanan kepada warga di RT-RT dalam lingkup RW, lalu pengurus RT dapat terbantu dalam hal pemantauan iuran warga atau pemasukan lain dari warga yang akan dilakukan dalam jangka waktu tertentu, dan manajemen pelayanan keuangan di RT dapat lebih tertata, teratur dan mudah untuk dialokasikan ketika ada kegiatan warga.

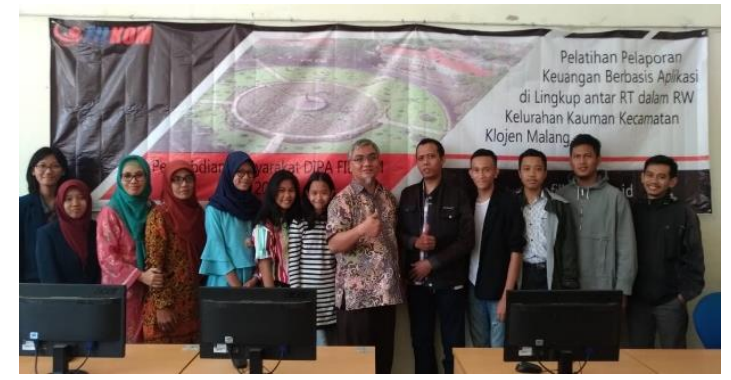

Gambar 2. Foto bersama setelah pelatihan

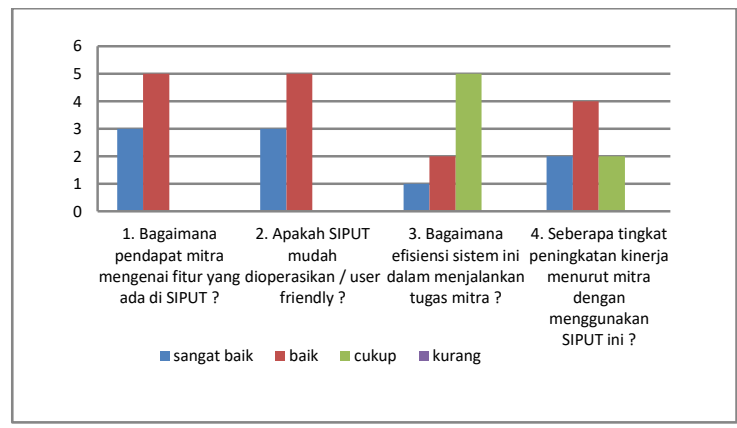

Gambar 3. Hasil Evaluasi Sistem

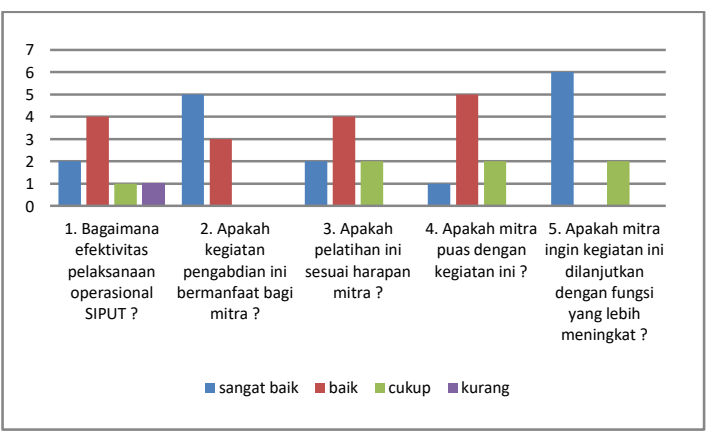

Gambar 4. Hasil Evaluasi Pelaksanaan Pelatihan

\section{DAMPAK DAN MANFAAT KEGIATAN}


Manfaat secara global dari SIPUT tersebut, yaitu dalam sistem informasi ini memiliki manfaat mulai bagi staff RT hingga masyarakat luas. Staff RT dapat melakukan berbagai kegiatan manajemen seperti membuat manajemen keuangan, manajemen surat, dan manajemen kegiatan warga. Sedangkan bagi masyarakat atau warga RT-02 dan RT-03 RW-03 Kelurahan Kauman dapat mengakses informasi seputar transaksi keuangan yang terjadi pada RT-02 dan RT-03 RW-03 Kelurahan Kauman. Secara umum, dengan diterapkannya sistem informasi SIPUT ini pelayanan dari staff RT dapat meningkat serta memudahkan warga dalam melakukan proses pemantauan transaksi keuangan yang terjadi di lingkungan RT.

\section{KESIMPULAN}

Aplikasi Sistem Pengelola Keuangan untuk RT. Ini telah berhasil dijalankan, yang dibagi dalam 3 jenis user, yaitu user umum atau dalam kasus ini merupakan warga RT-02 dan RT-03 RW-03, admin serta operator yang merupakan staff RT02 dan RT-03 RW-03 Kelurahan Kauman. Kelebihan Sistem Pengelola Keuangan RT (SIPUT) ini dibandingkan dengan sistem sejenis lainnya adalah:

- SIPUT dapat diakses dalam berbagai platform baik perangkat PC maupun mobile karena sistem informasi ini terhubung dengan internet

- Karena terhubung dengan internet, maka sistem ini dapat dibuka dimana pun user berada

- Menggunakan tampilan yang menarik serta user friendly

- Staff RT-02 dan RT-03 RW-03 Kelurahan Kauman dapat dengan mudah melakukan manajemen pengelolaan keuangan dengan cepat dan akurat, sehingga kinerja mereka menjadi lebih baik.

Saran ke depannya, diharapkan pada pengabdian masyarakat selanjutnya dapat menambahkan beberapa Modul maupun fitur baru lagi yang telah disesuaikan dengan kebutuhan masyarakat setempat, dengan harapan dapat memberikan tambahan kelengkapan akan suatu SIPUT yang dapat dikatakan terus dikembangkan pada setiap periode waktu pelaksanaan kegiatan. Kemudian diharapakan juga mampu menambah daya tarik masyarakat tentang penggunaan teknologi informasi secara mudah dan profesional serta dapat diterapkan di RT lain-lainnya.

\section{DAFTAR PUSTAKA}

[1] BI. "Pengelolaan Keuangan (Modul Pelatihan)". 2014.

http://www.bi.go.id/id/perbankan/keua nganinklusif/edukasi/Contents/Pengelo laan\%20Keuangan\%20Modul\%20Pela tihan.pdf $>$.

[2] Sejarah Kauman. "Pola Permukiman Kampung Kauman Kota Malang" http://elibrary.ub.ac.id/bitstream/12345 6789/23496/1/Pola-Permukiman-

Kampung-Kauman-Kota-Malang.pdf

[3] SK Rektor UB. "Buku Pedoman Kegiatan Akademik Universitas Brawijaya Tentang Pengabdian Masyarakat”. 2007-2008. http://oldsite.ub.ac.id/id/9_publication/ bppub/sk_rektor.php.

[4] Github. "Sistem Pengelola Keuangan RT (SIPUT)".2014. $<$ https://github.com/nadhirfr/siput> 